\title{
Assessment of serum carcinoembryonic antigen in colorectal cancer patients treated by surgery and chemotherapy
}

\author{
Shahbaa A. Al-Bayati \\ Department of Physiology, Ninevah College of Medicine, University of Mosul
}

\begin{abstract}
$\underline{\text { Received }}$
Accepted

25.7.2011

25.9.2011

ABSTRACT

Objective: Carcinoembryonic antigen (CEA) is a protein found in many types of cells associated with tumors and the developing fetus. The main use of CEA is as a tumor marker, especially with intestinal cancer. This study was designed to evaluate the effect of surgery and chemotherapy on the level of CEA.

Patients and methods: The study was carried out in Al-Jamhoory Teaching Hospital in Mosul from January to July 2010. Thirty patients with colorectal carcinoma were treated by surgical removal of the cancer and chemotherapy. Blood samples were taken from the patients one week before surgery and other blood samples were taken one week after surgery. Third blood samples were taken after one week of the first cycle of chemotherapy. Serum carcinoembryonic antigen, ALP (alkaline phosphatase), ALT (alanine aminotransferase), total serum bilirubin (TSB), and albumin were estimated from the samples.

Results: After surgery serum CEA and WBCs were decreased significantly $(\mathrm{P}<$ 0.001). Serum ALP was also decreased significantly $(P<0.05)$, while serum ALT, $\mathrm{TSB}$, and albumin were not changed significantly after surgery compared with the results before surgery. After chemotherapy, serum CEA and WBCs decreased significantly $(P<0.001)$ compared with the results after surgery. At the same time, serum ALP, ALT, TSB, and albumin did not change significantly after chemotherapy.

Conclusion: Surgical removal of tumor decreased CEA level, but it did not normalize. Serum CEA can be used as a marker for the effectiveness of the chemotherapy on colorectal cancer.
\end{abstract}

Keywords: Colorectal cancer, carcinoembryonic antigen, chemotherapy.

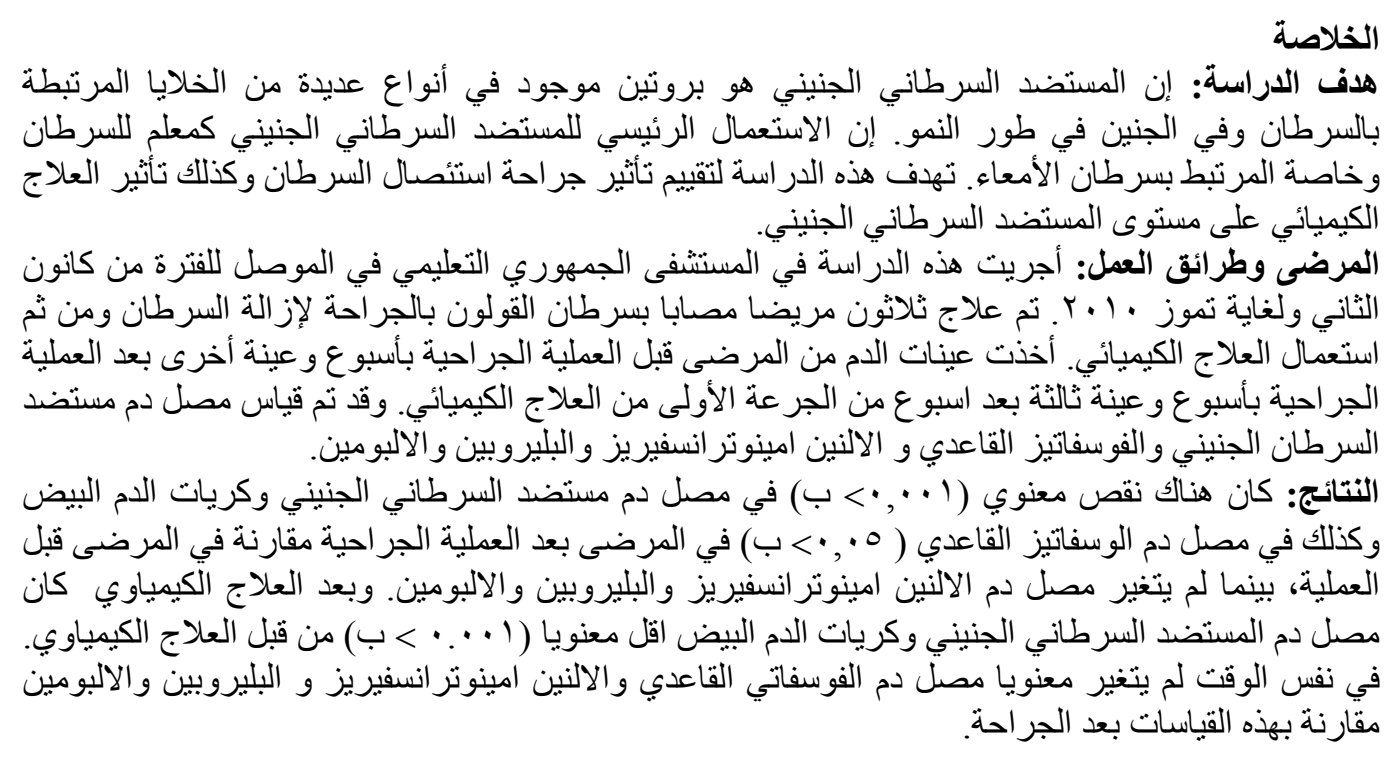




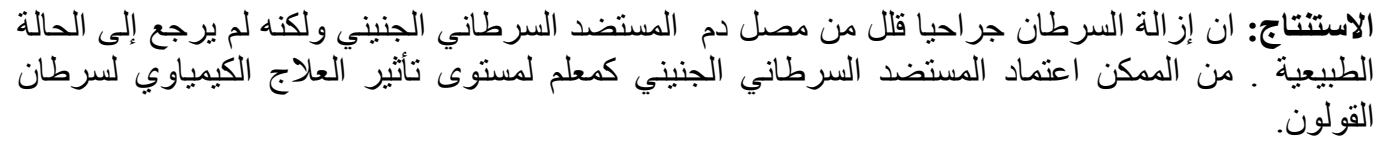

$C$ arcinoembryonic antigen (CEA) was 4 originally described by Gold and Freeman in 1965, its presence was demonstrated in fetal gut tissue and in tumors from gastrointestinal tract ${ }^{1,2}$. Subsequently, CEA was detected in the circulation of patients and recognized as a serum marker for colorectal cancer ${ }^{3}$.

CEA is recommended as the reference serum marker (standard) and can be used to predict operability of recurring tumor ${ }^{4}$. CEA is also used for monitoring treatment of advanced disease $^{5}$. However, serum CEA antigen level is not useful to screen for colon cancer because of insufficient sensitivity especially, for patients who have early and highly curable colon cancer ${ }^{6}$.

Combined pre-and postchemoradiotherapy CEA levels could be useful as a prognostic factor for disease free survivals with rectal cancer who undergo neoadjuvent chemoradiotherapy and curative resection ${ }^{7}$. In addition, postchemoradiotherapeutic CEA levels $<5$ $\mathrm{ng} / \mathrm{mL}$ is a favorable prognostic factor for rectal cancer and is associated with increased rate of earlier disease staging and complete tumor regression. ${ }^{8}$

The aim of this study was conducted in order to evaluate the effect of surgical removal and chemotherapy treatment on the level of CEA in colorectal cancer.

\section{Patients and Methods}

This study was conducted at Aljamhoory Teaching Hospital, Mosul, Iraq, during the period from January to July 2010 . Thirty patients (15 males and
15 females) with colorectal cancer diagnosed by specialist using triple assessment involved clinical feature, ultrasound, mammography and fine needle aspiration cytology. The patients were treated by surgical removal of the cancer. Chemotherapy was stared after two weeks of the surgery. Chemotherapy included combination of 5-fluorouracil $450 \mathrm{mg} / \mathrm{m}^{2}$ and leucovorin $20 \mathrm{mg} / \mathrm{m}^{2}$ daily for 5 days, given by infusion and the cycle was repeated every 28 days for six cycles. Blood samples were taken from the patients one week before surgery and other blood samples were taken after one week of surgery. Other blood samples were taken after one week of the first cycle of chemotherapy. Blood samples were analyzed for serum carcinoembryonic antigen, ${ }^{9} \mathrm{WBCs}$, and $\mathrm{ALP}^{10}$ (alkaline phosphatase), $\mathrm{ALT}^{11}$ (alanine aminotransferase), $\mathrm{TSB}^{12}$ (total serum bilirubin), and albumin were estimated. The estimation of serum CEA based on fluorescence immunoassay technology using sandwich immune assay. ${ }^{9}$

Data are presented as means $\pm \mathrm{SD}$ and were analyzed by using paired t-test to compare between parameters for the follow up study using SPSS Version 10. $P$ value less than 0.05 was considered significant.

\section{Results}

Table 1 shows significant decreases ( $\mathrm{P}$ $<0.001)$ in the serum level of CEA, ALP and WBCs after surgery compared with these parameters before surgery. 
Table 1. Carcinoembryonic antigen (CEA), liver function tests and WBCs in colorectal cancer patients treated with surgical removal and chemotherapy

\begin{tabular}{|c|c|c|c|c|c|c|}
\hline Parameters & CEA & WBCs & ALP & ALT & TSB & Albumin \\
\hline Before surgery & $\begin{array}{c}5.44 \\
\pm 1.53 \\
\end{array}$ & $\begin{array}{c}8.17 \\
\pm 2.4 \mathrm{E} 09 \\
\end{array}$ & $\begin{array}{c}48.77 \\
\pm 24.08 \\
\end{array}$ & $\begin{array}{r}12.17 \\
\pm 6.14 \\
\end{array}$ & $\begin{array}{r}9.3 \\
\pm 4.5 \\
\end{array}$ & $\begin{array}{c}43.17 \pm 5.0 \\
5 \\
\end{array}$ \\
\hline After surgery & $\begin{array}{c}4.29 \\
\pm 1.29^{\mathrm{a}}\end{array}$ & $\begin{array}{c}7.43 \\
\pm 2.1 \\
\text { E09 }\end{array}$ & $\begin{array}{c}46.03 \\
\pm 22.66^{\mathrm{a}}\end{array}$ & $\begin{array}{l}12.93 \\
\pm 5.21\end{array}$ & $9.83 \pm 4.4$ & $\begin{array}{c}42.97 \pm 4.1 \\
6\end{array}$ \\
\hline $\begin{array}{l}\text { After } \\
\text { chemotherapy }\end{array}$ & $\begin{array}{c}3.38 \\
\pm 1.17^{\mathrm{b}}\end{array}$ & $\begin{array}{c}6.60 \pm 1.8 \\
\text { E09 }\end{array}$ & $\begin{array}{c}4.3 \\
\pm 19.81\end{array}$ & $\begin{array}{l}13.13 \\
\pm 4.92\end{array}$ & $\begin{array}{c}9.5 \\
\pm 4.3\end{array}$ & $42.07 \pm 3.9$ \\
\hline
\end{tabular}

A: $P \leq 0.001$ VS before surgery; b: $P \leq 0.001$ VS after surgery

ALP: alkaline phosphatase. ALT: alanine aminotransferase, TSB: total serum biluribin.

Table 2. Distribution of the patients with colorectal cancer according to the level of their serum carcinoembryonic antigen (CEA)

\begin{tabular}{|l|c|c|c|c|c|}
\hline \multirow{2}{*}{ Patients } & \multicolumn{5}{|c|}{ Serum CEA ng/mL } \\
\cline { 2 - 6 } & $\leq 3$ & $3.1-4$ & $4.1-5$ & $>5$ & $\begin{array}{c}\text { Total number } \\
\text { of patients }\end{array}$ \\
\hline $\begin{array}{l}\text { Before } \\
\text { surgery }\end{array}$ & --- & 3 & 21 & 6 & 30 \\
\hline $\begin{array}{l}\text { After surgery } \\
\text { After } \\
\text { chemotherapy }\end{array}$ & 6 & 14 & 6 & 4 & 30 \\
\hline
\end{tabular}

Serum ALP was decreased significantly $(p<0.05)$, while serum ALT, TSB, and albumin were not changed significantly after surgery compared with the results before surgery.

After chemotherapy, serum CEA decreased significantly $(p<0.001)$ compared with the results after surgery as shown in Table 1. At the same time, serum ALP, ALT, TSB, and albumin did not change significantly after chemotherapy compared with that after surgery (Table1).

Table 2 shows that serum CEA for all patients before surgery was higher than $3 \mathrm{ng} / \mathrm{mL}$. Most of the colorectal patients were still had higher serum CEA than $3 \mathrm{ng} / \mathrm{mL}$ after surgical removal of the cancer. However, more than $50 \%$ of

the patients had equal or less than 3 $\mathrm{ng} / \mathrm{mL}$ and only 6 patient had serum level $2 \mathrm{ng} / \mathrm{mL}$ after the first cycle of chemotherapy

\section{Discussion}

An elevated level of serum CEA preoperatively is a poor indicator: the high the serum level of CEA the more likely the cancer is extensive and will recurrence postoperatively. ${ }^{6}$ The diagnostic value in the follow up study after curative surgery suggests cancer recurrence. $^{13}$ A cut off value of 2.2 $\mathrm{ng} / \mathrm{mL}$ may provide an ideal balance of sensitivity and specificity of CEA. ${ }^{14}$ In the present patients, the mean value of serum CEA was higher than the

mentioned cut off value, In addition to that, serum CEA were higher than 7 $\mathrm{ug} / \mathrm{mL}$ for 5 patients indicating bad prognosis.

The distribution of the present colorectal patients according to their serum CEA showed that surgical 
removal of the cancer did not retuned serum CEA to normal value for most of the patients. Chemotherapy treatment retuned only 18 patients out of 30 patients to the normal value. These results, therefore, indicated that chemotherapy is important for the cure of the patients ${ }^{7}$.

In the present study, serum level of CEA was decreased significantly after removal of the cancer. Veiged ${ }^{15}$ confirmed the prognostic value of serum CEA in particular its $t$ half life following surgery for colorectal carcinoma. However, serum CEA is a test with high specificity but insufficient sensitivity for detecting colorectal cancer. $^{14}$

After cancer resection, serum CEA decreased significantly though still higher than normal value. Cappell ${ }^{16}$ found that after complete colon cancer resection, serum level of CEA almost normalize. Failure to normalize postoperatively suggests incomplete resection. A sustained and progressive rise after post operative normalization strongly suggest cancer recurrence. ${ }^{16}$ Accordingly, serum CEA may not give the cure of the disease, since 24 patients out of 30 had serum CEA more than $3 \mathrm{ng} / \mathrm{mL}$.

In the present study, WBCs were higher than normal level and decreased after removal of the cancer. Lee et $\mathrm{al}^{17}$ found an association between elevated WBCs and colonic cancer with an increase in both mortality and incidence of colon cancer. The decrease of the WBCs in the present patients indicated the removal of the cancer

The most useful application of CEA is in the detection of liver metastasis from colorectal cancer. ${ }^{18}$ Therefore, liver function tests were determined, in the present patients, in order to detect the metastasis to the liver in accordance with the high level of serum CEA. The liver function tests were within normal indicating the cancer of the patients did not reach the liver.

In conclusion, serum CEA was decreased after resection of colorectal cancer, but it did not normalize. Serum CEA can be used as a marker for the effectiveness of the chemotherapy on colorectal cancer.

\section{Acknowledgement}

This study was supported by Ninevah College of Medicine.

\section{References}

1. Gold P, Freeman SO. Demonstration of umor specific antigens in human colonic carcinomata by immunologicl tolerance and absorption techniques. J Exp Med 1965;121:439.

2. Gold P, Freeman SO. Specific carcinoembryonic antigens of the human digestive suystem. J Exp Med 1965:122:467.

3. Wang JY, tang R, chiang JM. Value of carcinoembryonic antigen in the management of colorectal cancer. Dis Colon Rectum 1994;37:272-7.

4. Eche N, Pichon MF, Quillen V, et al. Standards, options and recommendations for tumor markers in colorectal cancer. Bull Cancer 2001;88:1177-206.

5. European Group on tumor Markers. Clinical utility of biochemical markers in colorectal cancer. Europ. J cancer 2003; 39:718-727.

6. Grem JL, Steinberg SM, Chen AP, et al. The utility of monitoring carcin- oembryonic antigen during systemic therapy for advanced colorectal cancer. Oncol Rep 1998;5:559-67.

7. Jang NY, Kang SB, Kim DW, et al. The role of carcinoembryonic antigen after neoadjuvant 
chemoradiotherapy in patients with rectal cancer. Dis Colon Rectum 2011;54:245-52.

8. Perez RO, Sao Julias GP, HabrGama D, et al. The role of carcinoembryonic antigen in predicting response and survival to neoadjuvent choradiotherapy for distal rectal cancer. Dis Colon Rectum 2009;52:1137-43.

9- Oh SW, Moon JD, Park SY, et al. Evaluation of fluorescence hs-CRP immunoassay for point-of-care testing. Clin Chim Acta 2005;356:172-177.

10- Kind PRN, King EJ. Estimation of plasma phosphatase by determination of hydrolysed phenol with amino-antipyrine. JClin Path 1954;7:322-26.

11-Bergmeyer. Opimization of methods for aspartate aminotransferase and alanine aminotransferase. Clin Chem Arch 1978;24:58-73.

12-Matinek RG. Improved micromethod for determination of serum bilirubin. Clin Chim Acta;13:161-70.

13- Komer H, Soreide K, Stokkeland PJ, et al. Diagnostic accuracy of serum carinoembryonic antigen in recurrent colorectal cancer: a receiver operating characteristic curve analysis. Ann Surg Oncol 2007; 14:417-23.

14- Tan E, Gouvas N, Nicholls RG, et al. Diagnostic precision of carcinoembryonic antigen in the detection of recurrence of colorectal cancer. Surg Oncol 2009;18:15-24.

15- Veingerl B. Serum carcinoembryonic antigen levels in patients operated for colorectal carcinoma. Wien Klin Wochenschr 2001;113 supp3:32-8.

16- Cappell MS. Pathophysiology, clinical presentation, and management of colon cancer. Gastroenterol Clin N Am 2008;37:1-24.

17- Lee YJ, Lee HR, Nam CM, et al. White blood cell count and the risk of colon cancer. Yonsei Med J 2006;31:646-56.

18-Duffy MJ. Carcinembryonic antigen as a marker for colorectal cancer: is it clinically useful? Clin Chem 2001;47:624-30. 